\title{
G

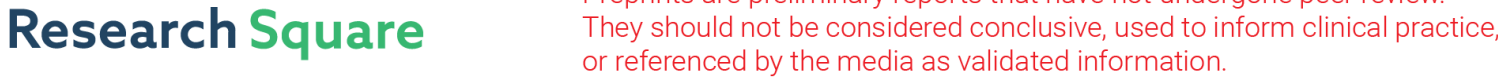 \\ Peatland Degradation Reduces Microbial Richness and Alters Microbial Functions in an Australian Peatland
}

C Birnbaum ( $\nabla$ christina.birnbaum@rmit.edu.au )

RMIT University

Jennifer Wood

La Trobe University, Physiology, Anatomy and Microbiology, Science Drive, Bundoora, VIC 3086 Australia Erik Lilleskov

USDA Forest Service, Northern Research Station, 410 Maclnnes Dr, Houghton, MI 49931, USA

\section{Louis James Lamit}

Department of Biology, Syracuse University, 107 College Place, Syracuse, NY 13244, USA; and, Department of Environmental and Forest Biology, State University of New York College of Environmental Science and Forestry, 1 Forestry Drive, Syracuse, New York 13210, USA.

\section{James Shannon}

Department of Ecology, Environment and Evolution, La Trobe University

\section{Matthew Brewer}

La Trobe University, Physiology, Anatomy and Microbiology, Science Drive, Bundoora, VIC 3086 Australia

\section{Samantha Grover}

Applied Chemistry and Environmental Science, School of Science, RMIT University Melbourne VIC 3001, Australia

\section{Research Article}

Keywords: peatland, archaea, bacteria, mycorrhizae, decomposition, soil carbon

Posted Date: January 14th, 2022

DOI: https://doi.org/10.21203/rs.3.rs-1252261/v1

License: (c) (1) This work is licensed under a Creative Commons Attribution 4.0 International License. Read Full License 


\section{Abstract}

Peatland ecosystems cover only $3 \%$ of the world's land area, however they store one-third of the global soil carbon (C). Peatlands play a central role in global $\mathrm{C}$ cycling as they contain more organic $\mathrm{C}$ than any other terrestrial ecosystem. Microbial communities are the main drivers of $\mathrm{C}$ decomposition in peatlands, yet we have limited knowledge of their structure and function. We investigated the vertical stratification of prokaryote and fungal communities from Wellington Plains peatland in the Australian Alps. Within the peatland complex, bog peat was sampled from the intact peatland and dried peat from the degraded peatland along a vertical soil depth gradient (i.e., acrotelm, mesotelm and catotelm). We analysed the prokaryote and fungal community structure, predicted functional profiles of prokaryotes using PICRUSt and assigned soil fungal guilds using FUNGuild. We found that the structure and the function of prokaryotes was vertically stratified in the intact bog. Carbon, manganese, nitrogen, lead and sodium best explained the prokaryote composition. Prokaryote richness was significantly higher in the intact bog acrotelm compared to degraded bog acrotelm. Fungal composition remained similar across the soil depth gradient, however there was a considerable increase in saprotroph abundance and decrease in endophyte abundance along the vertical soil depth gradient. The abundance of saprotrophs and plant pathogens was two-fold higher in the degraded bog acrotelm. Manganese, nitrogen, electrical conductivity and water table level $(\mathrm{cm})$ best explained the fungal composition. Our results demonstrate that both fungal and prokaryote communities are shaped by soil abiotic factors and peatland degradation reduces microbial richness and alters microbial functions. Thus, current and future changes to the environmental conditions in these peatlands may lead to altered microbial community structure and associated functions which may have implications for broader ecosystem function changes in peatlands.

\section{Introduction}

Although peatlands cover only $3 \%$ of the world's land area, they store one-third of global soil carbon (C) [1]. Peatland ecosystems play a central role in global $\mathrm{C}$ cycling as they contain more organic $\mathrm{C}$ than any other terrestrial ecosystems [2, 3], while also releasing carbon dioxide $\left(\mathrm{CO}_{2}\right)$ and methane $\left(\mathrm{CH}_{4}\right)$ to the atmosphere via decomposition $[4,5]$. Where decomposition is hindered, organic matter can accumulate, creating peat soil, whereas when the system is disturbed net $\mathrm{C}$ will be released [4]. Hydrology plays a critical role in balancing the accumulation or decomposition of plant material in peatlands. For example, in anoxic conditions peat soil can accumulate when water-logging hinders the breakdown of plant material resulting in plant growth exceeding decomposition $[6,7]$. Climate change will affect the $C$ dynamics in both natural and disturbed peatlands as has been reported in a number of studies [8-10]. This has led to an increasing interest in peatland research and the above- and below-ground drivers of ecosystem processes which may facilitate restoring peatland ecosystem functions, including $\mathrm{C}$ sequestration, in disturbed peatlands [11].

In natural peatlands microbial communities and associated decomposition processes are vertically stratified with depth, which is caused by changes in redox conditions, C quality and oxygen $\left(\mathrm{O}_{2}\right)$ 
availability [11-14]. The highest amount of decomposition, biological metabolism and nutrient cycling occurs in the acrotelm (aerobic soil layer), followed by the mesotelm where conditions fluctuate between anoxic and oxic depending on the water table levels, which results in shifting metabolic processes [1519]. Finally, litter enters the water-saturated catotelm, which is permanently anoxic, where biological material is decomposed slowly, predominantly by prokaryotes [20]. These changes in vertical abiotic conditions are likely to lead to changes in fungal and prokaryotic community composition, diversity and function as well. Our understanding of the fungal, especially mycorrhizal and free-living saprotrophic fungi, in peatland carbon cycling is very limited [21-23] in comparison with the prokaryotic guilds (e.g., methanogens and methanotrophs) that have received more research attention [24, 25]. This knowledge gap highlights the need to further explore the importance of fungal communities in peatlands.

Knowledge to date suggests that in the oxic upper layers, i.e., the acrotelm, aerobic decomposition is driven by saprotrophic fungi rather than bacteria [26-28]. As organic matter is degraded from litter to less labile organic matter it promotes succession of fungal communities with different growth traits and enzymatic capabilities (i.e. temporal niche partitioning), e.g., from saprotrophic to mycorrhizal communities $[29,30]$. Similarly, bacterial communities have been reported to change in composition and specialization along a vertical soil gradient with a general decrease in their diversity $[11,13,14,28,31]$. Specifically, at intermediate depths in peatlands, the mesotelm, which has been termed the "hot spot" of microbial diversity and activity, lies the interface between oxic and anoxic layers where the water table fluctuates and the simultaneous presence of $\mathrm{CH}_{4}$ and $\mathrm{O}_{2}$ facilitates conditions for methanotrophic bacteria (methanotrophs) [11]. Methanotrophs metabolise $\mathrm{CH}_{4}$ to produce biomass and $\mathrm{CO}_{2}$ [32]. Taken together, microbial communities in peatlands play an important role in greenhouse gas emissions, especially $\mathrm{CO}_{2}$ and $\mathrm{CH}_{4}$, as well as the ongoing sequestration of carbon in the peat itself and thus it is important to understand belowground microbial diversity and ecology to better predict global $\mathrm{C}$ dynamics, especially in a warming climate.

The balance between greenhouse gas emissions and carbon sequestration in peatlands may shift as a result of disturbance (e.g., grazing, fire, changes in hydrology, nutrient deposition, increased temperatures). For example, drainage of peatlands for agricultural/grazing purposes has been a management strategy in many countries which leads to changes to water table regime [11]. Water table position fluctuations or declines in peatlands will be accompanied by subsequent changes to the microbial communities and their functioning [11]. For instance, fungal communities have been shown to decline in richness and diversity following drainage and changes in water table depths [33, 34]. Bacterial composition has been shown to be unaffected by short-term water table drawdown, whereas long-term changes to water table did cause shifts in bacterial composition $[35,36]$. Drainage has been shown to decrease the abundance of methanotrophs whose ecological niche is dependent on the position of the water table [37]. Overall, previous studies suggest that drainage of peatlands may decrease the diversity and alter the net functioning of fungal and bacterial across the soil depth gradient (i.e., acrotelm, mesotelm and catotelm). 
The objective of this study was to compare prokaryotic and fungal community structure from two bogs located in the Australian Alps on Wellington Plains peatland (one degraded following historic grazing activity, the other intact) along a vertical soil depth gradient. Peat soils in the Australian Alps comprise a mosaic of intact bog peats and disturbed dried peats [38]. Dried peat in this region is likely to be derived from bog peat as a consequence of bog drainage caused by cattle grazing damage [39]. Peat soils have attracted renewed attention following bushfires $(1998,2003,2006)$ and an end to cattle grazing $(2005)$ in the Australian Alps which has led to peatland restoration work [40-42]. Understanding the belowground microbial structure and associated carbon cycling in peat soils is central to conducting informed rehabilitation works in the Australian Alps [43].

Therefore, we assessed fungal and prokaryotic community structure and predicted prokaryotic functional gene types using PICRUSt and fungal guilds using FUNGuild. We hypothesized that prokaryotic and fungal structure will 1) be vertically stratified in the intact bog and 2) differ in disturbed dried peat as compared to the intact bog peat due to the variation in the environmental and edaphic factors. These results will contribute to better understanding the effect of disturbance on belowground microbial dynamics in peatlands and the associated effects on $\mathrm{C}$ turnover and inform scientifically-grounded management and restoration of peatlands.

\section{Methods}

\section{Study site description and sample collection}

Our study site is located in the Australian Alps on Wellington Plains peatlands. Detailed description of Wellington Plains location (see Fig. 1. in Grover et al. 2011), geomorphology and vegetation can be found in Grover and Baldock 2010 and Grover et al. 2011. Briefly, peatlands occur beneath springs and seepages where groundwater reaches the surface and along the valley bottom [39]. The carbon chemistry and decomposition processes of these peats are described in Grover and Baldock $(2010,2012)$. The properties of the peat from Wellington Plains are comparable with those of Sphagnum peatlands in the northern hemisphere [44].

The vegetational composition of the peatland has remained stable since its formation [45]. The most extensive peat types are bog peat and dried peat; the dominant vegetation in bog peat is Sphagnum cristatum, Empodisma minus, Baloskion australe, Epacris paludosa, Richea continentis, Baeckea gunniana, Astelia alpina and Carex gaudichaudiana and in the dried peat is Empodisma minus, Baloskion australe, Poa costiniana, Epacris paludosa, Baeckea gunniana and Carex gaudichaudiana [39]. Whilst there is overall much overlap in the vegetation between the two peat types, the main distinction between bog and dried peat vegetation is the lack of hydrophilic Sphagnum on the dried peat and the lack of $P$. costiniana on the bog peat [39].

A total of twelve soil samples from intact bogs ( $\left.-37^{\circ} 29^{\prime} 43^{\prime \prime}, 146^{\circ} 49^{\prime} 44^{\prime \prime}\right)$ and degraded dried peatlands following grazing activity $\left(-37^{\circ} 29^{\prime} 43^{\prime \prime}, 146^{\circ} 49^{\prime} 52^{\prime \prime}\right)$ were sampled on $7 \otimes 8$ March 2015 . Our samples 
were a subset of those from the Global Peatland Microbiome Project, a larger study aimed at characterizing microbial communities and biogeochemistry in the Earth's peatlands (Lamit and Lilleskov et al. unpublished, Seward et al. 2020). Intact bog samples were collected from triplicate sites at three depths: $10 \otimes 20 \mathrm{~cm}$ (acrotelm), $30 \otimes 40 \mathrm{~cm}$ (mesotelm), and $60 \otimes 70 \mathrm{~cm}$ (catotelm) below the peat surface from pits excavated by hand using serrated knife (Seward et al. 2020). In the dried peat, samples were collected from triplicate sites at $10-20 \mathrm{~cm}$ only, due to shallow peat profiles. Soil sampling equipment was carefully sterilized with ethanol between replicates or replaced between each sample collection and between site. Peat samples were kept on dry ice in a cooler in the field before being transferred to storage in $-80^{\circ} \mathrm{C}$ freezer upon returning to the laboratory at La Trobe University the next day.

\section{Environmental and soil chemistry data}

Environmental data collected for each site and sample included Sphagnum and vegetation cover, pore water $\mathrm{pH}$, electrical conductivity, and depth to water table $(\mathrm{cm})$. Understory plant data was collected in $1 \mathrm{~m}^{2}$ plots and canopy cover was taken above the core location (Table 1) (Seward et al. 2020). Peat soil samples were analysed for peat $\mathrm{pH}(2: 1$ water to peat slurry) and a number of chemistry variables including C (\%), N (\%), S (\%), Al (mg/kg), Ca (mg/kg), Fe (mg/kg), K (mg/kg), Mg (mg/kg), Mn (mg/kg), $\mathrm{Na}$ (mg/kg), P (mg/kg), Pb (mg/kg), Zn (mg/kg).

Freeze dried soil samples were ground using a Wiley Mini Mill (Thomas Scientific, Swedesboro, NJ, USA) with size 40 mesh at Laurentian University (Sudbury, Ontario, Canada). One subsample from each peat sample was weighed (ca. $75 \mathrm{mg}$ each on a balance with $0.00001 \mathrm{~g}$ readability) and pressed with W-oxide catalyst (ca. $150 \mathrm{mg}$ ) in Al foil prior to analysis on a VarioMacro CNS Analyzer (Elementar Gmbh, Langenselbold, Germany). Precision was confirmed using blanks and sulfadiazine for $\mathrm{C}, \mathrm{N}$, and $\mathrm{S}$ and calibration was done with QA standards (NIST-1515-SRM).

A second ca. 1-g sub-sample was weighed in acid-washed and "pre-ashed" ceramic crucible and combusted in a muffle furnace at $550^{\circ} \mathrm{C}$ for $6 \mathrm{~h}$. Remaining ash was weighed to determine loss on ignition and then digested two times at $110^{\circ} \mathrm{C}$ for $3.5 \mathrm{~h}$ in $10 \mathrm{ml}$ of $\mathrm{HF}$ and $\mathrm{HCl}$ (until dried), subsequently in $\mathrm{HNO}_{3}$ and $\mathrm{HCl}$, and then in a mix of all 3 acids (each subsequent digestion step also lasted 3.5h, allowing drying). Samples were eluted in $50 \mathrm{ml}$ distilled, deionized $\mathrm{H}_{2} \mathrm{O}$ and analyzed on a Varian 810 ICP-MS for $\mathrm{Al}, \mathrm{Ca}, \mathrm{Fe}, \mathrm{K}, \mathrm{Mg}, \mathrm{Mn}, \mathrm{Na}, \mathrm{P}, \mathrm{Pb}$ and Zn (now part of Agilent Technologies, Santa Clara, California, USA), with dilutions to match to the instrument detection limits. Duplicate samples, blanks that were subjected to all processing steps minus peat samples, and standard organic reference material (NIST spinach and tomato leaves) were included every 20 samples to ensure data quality.

The water table was monitored in the bog peat and the dried peat using 2 TruTrack water height loggers (WT-HR; TruTrack Ltd, Christchurch, New Zealand) from 2008-2015. The TruTrack water height loggers were suspended in perforated $4 \mathrm{~cm}$ PVC tubing and logger position relative to the surface was recorded. The tubing was fitted with a cap to prevent rain or snow water from entering. The bog peat is deeper than the dried peat and thus a $100 \mathrm{~cm}$ long WT-HR 1000 logger was used in the bog peat and a $25 \mathrm{~cm}$ long WT-HR 250 was used in the dried peat. Both loggers were configured to read at 2 hourly intervals, and 
data transfer was carried out 6-9 monthly using Omni7 software (Trutrack Ltd, Christchurch, New Zealand). 
Table 1

Peatland environmental conditions and vegetation composition. $\mathrm{pH}$, electrical conductivity, depth to water table $(\mathrm{cm})$, total species richness and vegetation composition and cover \% are at a Core level. The mycorrhizal associations of listed species are in Supplementary Table 1.

\begin{tabular}{|c|c|c|c|c|c|c|c|}
\hline $\begin{array}{l}\text { Core } \\
\#\end{array}$ & $\begin{array}{l}\text { Peatland } \\
\text { condition }\end{array}$ & $\begin{array}{l}\text { Soil } \\
\text { depth } \\
\text { analysed }\end{array}$ & $\mathrm{pH}$ & $\begin{array}{l}\text { Electrical } \\
\text { conductivity } \\
(\mathrm{mS} / \mathrm{cm})\end{array}$ & $\begin{array}{l}\text { Depth } \\
\text { to } \\
\text { water } \\
\text { table } \\
\text { (cm) }\end{array}$ & $\begin{array}{l}\text { Total } \\
\text { plant } \\
\text { species } \\
\text { richness }\end{array}$ & $\begin{array}{l}\text { Vegetation composition } \\
\text { and cover \% }\end{array}$ \\
\hline \multirow{3}{*}{$\begin{array}{l}\text { Core } \\
1\end{array}$} & \multirow[t]{3}{*}{ Intact } & \multirow{3}{*}{$\begin{array}{l}10,30 \\
\text { and } 60 \\
\mathrm{~cm}\end{array}$} & \multirow[t]{3}{*}{4.67} & \multirow[t]{3}{*}{54} & \multirow[t]{3}{*}{50} & \multirow[t]{3}{*}{5} & - Canopy cover $(0 \%)$ \\
\hline & & & & & & & $\begin{array}{l}\text { - Understory: Baloskion } \\
\text { australe (40\%), } \\
\text { Empodisma minus } \\
\text { (30\%), Epacris } \\
\text { paludosa (20\%), } \\
\text { Baeckea gunniana } \\
(10 \%),\end{array}$ \\
\hline & & & & & & & $\begin{array}{l}\text { - Moss: Sphagnum } \\
\text { cristatum }(100 \%)\end{array}$ \\
\hline \multirow{3}{*}{$\begin{array}{l}\text { Core } \\
2\end{array}$} & \multirow[t]{3}{*}{ Intact } & \multirow{3}{*}{$\begin{array}{l}10,30 \\
\text { and } 60 \\
\mathrm{~cm}\end{array}$} & \multirow[t]{3}{*}{4.87} & \multirow[t]{3}{*}{55} & \multirow[t]{3}{*}{52} & \multirow[t]{3}{*}{7} & - Canopy cover (0\%); \\
\hline & & & & & & & $\begin{array}{l}\text { - Understory: } \\
\text { Empodisma minus } \\
\text { (45\%), Baloskion } \\
\text { australe }(30 \%) \text {, Epacris } \\
\text { paludosa (30\%), } \\
\text { Baeckea gunniana } \\
\text { (10\%) and Astelia } \\
\text { alpina }(2 \%)\end{array}$ \\
\hline & & & & & & & $\begin{array}{l}\text { - Moss: Sphagnum } \\
\text { cristatum (80\%), } \\
\text { Unknown sp. (5\%) }\end{array}$ \\
\hline \multirow{3}{*}{$\begin{array}{l}\text { Core } \\
3\end{array}$} & \multirow[t]{3}{*}{ Intact } & \multirow{3}{*}{$\begin{array}{l}10,30 \\
\text { and } 60 \\
\mathrm{~cm}\end{array}$} & \multirow[t]{3}{*}{5.02} & \multirow[t]{3}{*}{37} & \multirow[t]{3}{*}{17} & \multirow[t]{3}{*}{8} & - Canopy cover (0\%); \\
\hline & & & & & & & $\begin{array}{l}\text { - Understory: } \\
\text { Empodisma minus } \\
(60 \%), \text { Baeckea } \\
\text { gunniana (25\%), } \\
\text { Baloskion australe } \\
(20 \%), \text { Epacris } \\
\text { paludosa (20\%); } \\
\text { Unknown shrub sp. } \\
(15 \%), \text { Unknown sp. } \\
(30 \%)\end{array}$ \\
\hline & & & & & & & $\begin{array}{l}\text { - Moss: Sphagnum } \\
\text { cristatum (30\%), } \\
\text { Unknown sp. (70\%) }\end{array}$ \\
\hline
\end{tabular}




\begin{tabular}{|c|c|c|c|c|c|c|c|}
\hline $\begin{array}{l}\text { Core } \\
\#\end{array}$ & $\begin{array}{l}\text { Peatland } \\
\text { condition }\end{array}$ & $\begin{array}{l}\text { Soil } \\
\text { depth } \\
\text { analysed }\end{array}$ & $\mathrm{pH}$ & $\begin{array}{l}\text { Electrical } \\
\text { conductivity } \\
(\mathrm{mS} / \mathrm{cm})\end{array}$ & $\begin{array}{l}\text { Depth } \\
\text { to } \\
\text { water } \\
\text { table } \\
(\mathrm{cm})\end{array}$ & $\begin{array}{l}\text { Total } \\
\text { plant } \\
\text { species } \\
\text { richness }\end{array}$ & $\begin{array}{l}\text { Vegetation composition } \\
\text { and cover \% }\end{array}$ \\
\hline \multirow{3}{*}{$\begin{array}{l}\text { Core } \\
4\end{array}$} & Dried & $10 \mathrm{~cm}$ & 4.35 & NA & 33 & 10 & - Canopy cover (0\%); \\
\hline & & & & & & & $\begin{array}{l}\text { - Understory: } \\
\text { Empodisma minus } \\
(40 \%), \text { Poa sp. }(30 \%), \\
\text { Baloskion australe } \\
(20 \%), \text { Baeckea } \\
\text { gunniana }(10 \%), \\
\text { Baeckea utilis (10\%), } \\
\text { Celmisia costiniana } \\
\text { (10\%), Hydrocotyle sp., } \\
\text { Solenogyne dominii, } \\
\text { Unknown sp. (5\%) }\end{array}$ \\
\hline & & & & & & & - Moss: Unknown sp. \\
\hline \multirow{3}{*}{$\begin{array}{l}\text { Core } \\
5\end{array}$} & Dried & $10 \mathrm{~cm}$ & 5.27 & 42 & 21 & 7 & - Canopy cover $(0 \%)$ \\
\hline & & & & & & & $\begin{array}{l}\text { - Understory: } \\
\text { Empodisma minus } \\
(50 \%), \text { Baloskion } \\
\text { australe }(40 \%), \text { Epacris } \\
\text { celata }(20 \%), \text { Celmisia } \\
\text { costiniana }(5 \%), \text { Poa } \\
\text { sp. }(30 \%), \text { Viola } \\
\text { betonicifolia }(5 \%)\end{array}$ \\
\hline & & & & & & & $\begin{array}{l}\text {-Moss: Unknown sp. } \\
(30 \%)\end{array}$ \\
\hline
\end{tabular}

\section{Molecular analysis and bioinformatics}

DNA was extracted using PowerSoil ${ }^{\circledR}$ DNA Isolation kit (Qiagen, USA) following the manufacturers protocol and cleaned using the PowerClean ${ }^{\circledR}$ kit, following the manufacturers protocol [46]. For detailed methods on microbial sequencing see Seward et al. (2020) and Wang et al. (2019). In brief, bacterial and fungal communities were amplified using the V4 region of SSU rRNA with 515 (GTGCCAGCMGCCGCGGTAA) and 806 (GGACTACHVGGGTWTCTAAT) primer pairing [47] and ITS2 region with ITS9 (GAACGCAGCRAAIIGYGA) [48] and ITS4 (TCCTCCGCTTATTGATATGC) [49] primer pairing, respectively. Samples were sequenced on the Next-Generation Sequencing Illumina MiSeq platform by the Department of Energy's Joint Genome Institute (Berkley, CA, USA).

Bioinformatic analyses were performed using QIIME2 [50]. Prior to denoising, primers were removed using Cutadapt and forward and reverse reads were truncated based on quality scores to 200 and $180 \mathrm{bp}$ respectively for $16 S$ data, and 240 and 200 bp respectively for ITS data. Denoising was performed using 
the QIIME2 DADA2 plugin which implements joining, quality filtering and chimera detection [50, 51]. During denoising of ITS data, the 5.8S (94 bases) and 28S (35 bases) flanks were trimmed from the ITS reads. All amplicon sequence variants (ASVs) were aligned with mafft and used to construct a phylogeny with fasttree2 [52]. Taxonomic assignment for $16 \mathrm{~S}$ and ITS ASVs was performed using the QIIME2 feature classifier plugin classify-sklearn naïve Bayes classifier [53] trained on either the V4 regions of the 16S rRNA gene extracted from the Greengenes 13_8 99\% OTU dataset [54] or on the full ITS region from the UNITE (v. 8.0, released 02.02.2019) dynamically classified reference dataset [55]. ITS data were further filtered by aligning ASV representative sequences against the UNITE reference data set using BLAST in QIIME2, and reads that did not match at least $\geq 70 \%$ of their length to fungi with a similarity of $\geq 75 \%$ were removed.

Prokaryote metabolic potential was based on abundances of MetaCyc metabolic pathways, predicted using PICRUSt2 [56]. Prokayotic metabolic pathway abundances were log10 transformed prior to downstream analyses. Fungi were assigned functional categories following ecological guild assignment using FUNGuild database [57]. After guild assignment, only ASVs that were assigned as "Highly Probable" and "Probable" were retained [58].

\section{Statistical analyses}

Prokaryotic and fungal composition, richness and diversity was compared separately across the intact bog depth gradient $(10,30$ and $60 \mathrm{~cm}, \mathrm{n}=9)$ and between intact and dried peat samples from $10 \mathrm{~cm}$ only $(n=5)$. Prior to analyses both ASV matrices were subsampled to equal depth using "rarefy_even_depth" without replacement function in "phyloseq" package (fungi to 72558 reads and bacteria 146570 reads per sample) [59]. To visually inspect whether soil depth and soil condition (intact vs dried peat) affected prokaryotic and fungal composition non-metric dimensional scaling (NMDS) based on Bray-Curtis dissimilarity index was carried out on subsampled data generated from the prokaryotic and fungal species matrix. To quantify differences in prokaryotic and fungal composition based on ASV matrices, Permutational multivariate analysis of variance (Permanova) was used with 9999 permutations in $\mathrm{R}$ package "vegan" with core set as a random factor [60]. Richness and diversity indices (i.e. observed ASV number, Chao1 index, Shannon index and Inverted Simpson index) were summarised using "estimate_richness" function in "phyloseq" package [59] and square-root transformed prior to analyses if they did not meet the assumptions of data homogeneity. Indicator species were determined using "multiplatt" function in "indicspecies" package with alpa value set to 0.05 and 999 permutations [61]. To assess the differences among soil depths and cores for the dependent variables, linear mixed models including cores, ASV richness and diversity indices were built using "ImerTest" package [62]. For intact peatland site analysis, the permanova mixed models and linear mixed models included Depth as a fixed factor and Core as a random factor. Fixed effects were tested with Satterwhite approximation. For intact vs dried peatland analysis, peatland condition was the fixed factor in permanova mixed model. One-way ANOVA was used to analyse richness and diversity of fungi and prokaryotes in the acrotelm of intact and dried peat samples. 
We performed dbRDA (distance-based canonical redundancy analysis) using R package "vegan" (Oksanen et al 2017) to assess the effect of soil chemistry, sample depth relative to water table as a variable, and vegetation on prokaryotic and fungal community composition using the same dissimilarity matrix as for the NMDS. For all environmental variables we first performed a forward selection using "ordistep" function with 9999 permutations to identify the environmental variables significantly explaining variation in community composition. Where dbRDA models were significant (Table 2), summaries of redundancy analyses (dbRDA) statistics for redundancy axes are presented. Additionally, a summary of permutation tests for dbRDA under the reduced model with 999 permutations for abiotic variables tested in the dbRDA analysis are presented. A heatmap and dendrograms for predicted prokaryote metabolic pathways were built with base R using the heatmap ( ) function and scale set to "row" (i.e., soil depth). Water table position and log-transformed water table residency data was analysed using one-way ANOVA. All plots were prepared using "ggplot2" [63] and "RColorBrewer" [64] packages and analyses were performed in $\mathrm{R}$ [65].

\section{Results}

\section{Soil fungal and prokaryote community structure and diversity}

Fungal sequences were clustered into 1181 ASVs, which were further classified into six phyla with relative abundance $>0.01 \%$. In the intact bog, members of the Ascomycota $(73 \%)$ and Basidiomycota (19\%) were the most abundant phyla on average across cores (Fig. 2a). Notably, the relative abundance of Basidiomycota was highest in the mesotelm and acrotelm from core 2 and core 3, respectively (Fig. 2a). In comparison, the relative abundance of Basidiomycota was lowest (4\%) in the acrotelm in dried peat cores (Fig. 2a).

Prokaryotic sequences were clustered into 10365 ASVs, which were further classified into 25 phyla with relative abundance of at least $1 \%$. In the intact bog, members of the Proteobacteria (31.6\%) and Acidobacteria $(30.8 \%)$ were the most abundant identified phyla on average across all sites, followed by Verrucomicrobia (6.8\%) and Chloroflexi (6.7\%) (Fig. 2b). Notably, the relative abundance of Chloroflexi was on average fivefold higher in dried peat (21\%) than in intact bog cores (3.6\%) (Fig. 2b).

We found that fungal community composition and richness in the intact bog was similar across the soil depth gradient, whereas soil depth had a significant effect on prokaryote community composition, with NMDS ordination revealing a significant clustering of prokaryotes by soil depth (Table 2, Fig. 3a and b). Prokaryote richness was significantly greater in the intact bog than in the dried peat (Table 2). 
Table 2

Summary results for soil fungal and prokaryote structure in intact bog across three soil depths $(10 \mathrm{~cm}, 30$ $\mathrm{cm}, 60 \mathrm{~cm})$ and between intact bog and dried peat acrotelm only $(10 \mathrm{~cm})$ from Wellington Plains, Australia. Composition and soil chemistry hydrology factors was analysed using permanova mixed model and dbRDA, respectively.

\begin{tabular}{|c|c|c|c|c|}
\hline \multirow[t]{2}{*}{ Response variable } & \multicolumn{2}{|c|}{ Intact peatland } & \multicolumn{2}{|c|}{ Intact vs dried peatland } \\
\hline & Fungi & Prokaryotes & Fungi & Prokaryotes \\
\hline & $\underset{P}{\text { Depth } F(\mathrm{df})}$ & $\underset{P}{\text { Depth } F(\mathrm{df})}$ & $F(\mathrm{df}), P$ & $F(\mathrm{df}), P$ \\
\hline Composition & $\begin{array}{l}0.96(2,8) \\
0.17\end{array}$ & $\begin{array}{l}2.00(2,8), \\
0.027\end{array}$ & $\begin{array}{l}1.92(1,4), \\
0.2\end{array}$ & $3,04(1,4), 0.1$ \\
\hline \multicolumn{5}{|l|}{ Richness } \\
\hline Observed ASV & $\begin{array}{l}0.001(2,4) \\
0.99\end{array}$ & $\begin{array}{l}2.08(2,6) \\
0.21\end{array}$ & $\begin{array}{l}0.6(1,3) \\
0.49\end{array}$ & $\begin{array}{l}12.03(1,3) \\
0.04\end{array}$ \\
\hline Chao1 & $\begin{array}{l}0.02(2,4) \\
0.98\end{array}$ & $\begin{array}{l}2.08(2,6) \\
0.20\end{array}$ & $\begin{array}{l}0.54(1,3) \\
0.51\end{array}$ & $\begin{array}{l}12.05(1,3) \\
0.04\end{array}$ \\
\hline \multicolumn{5}{|l|}{ Diversity } \\
\hline Shannon index & $\begin{array}{l}0.89(2,6) \\
0.45\end{array}$ & $\begin{array}{l}1.63(2,6), \\
0.27\end{array}$ & $\begin{array}{l}0.27(1,3) \\
0.65\end{array}$ & $\begin{array}{l}3.08(1,3) \\
0.18\end{array}$ \\
\hline Inverted Simpson index & $\begin{array}{l}0.86(2,4) \\
0.49\end{array}$ & $\begin{array}{l}0.84(2,6) \\
0.47\end{array}$ & $\begin{array}{l}0.11(1,3) \\
0.76\end{array}$ & $\begin{array}{l}1.06(1,3) \\
0.38\end{array}$ \\
\hline $\begin{array}{l}\text { Soil chemistry and hydrology } \\
\text { factors }\end{array}$ & $\begin{array}{l}1.58(4,4) \\
0.001\end{array}$ & $\begin{array}{l}1.49(5,3) \\
0.006\end{array}$ & $\begin{array}{l}1.24(1,3), \\
0.03\end{array}$ & $\begin{array}{l}2.19(3,1) \\
0.08\end{array}$ \\
\hline
\end{tabular}

Fungal and prokaryote alpha diversity was not significantly influenced by the soil depth gradient in the intact bog (Table 3). However, we did find that prokaryote richness was significantly higher in the intact bog compared to dried peat (Table 3). 
Table 3

Alpha diversity indices (mean \pm SE) at different peat depths from intact $(n=3)$ and dried peat $(n=2)$ cores at Wellington Plains peatland, Australia. Different letters indicate significant difference $(P<0.05)$ between intact bog and dried peat prokaryote richness in the acrotelm.

\begin{tabular}{|llllll|}
\hline Depth (cm) & $\begin{array}{l}\text { Peatland } \\
\text { condition }\end{array}$ & $\begin{array}{l}\text { ASV } \\
\text { richness }\end{array}$ & $\begin{array}{l}\text { Chao } 1 \\
\text { index }\end{array}$ & $\begin{array}{l}\text { Shannon's } \\
\text { diversity }\end{array}$ & $\begin{array}{l}\text { Inverted Simpson's } \\
\text { index }\end{array}$ \\
\hline Prokaryotes & & & & & \\
\hline $10-20$ & Intact & $1599 \pm$ & $1600 \pm$ & $6 \pm 0$ & $220 \pm 37$ \\
\hline $30-40$ & Intact & $101^{\mathrm{a}}$ & $101^{\mathrm{a}}$ & & $295 \pm 16$ \\
\hline $60-70$ & Intact & $1537 \pm 64$ & $1917 \pm 65$ & $7 \pm 0$ & $229 \pm 66$ \\
\hline $10-20$ & Dried & $1044 \pm$ & $1044 \pm$ & $6 \pm 0$ & $164 \pm 36$ \\
\hline Fungi & & $124^{\mathrm{b}}$ & $124^{\mathrm{b}}$ & & \\
\hline $10-20$ & Intact & $178 \pm 17$ & $183 \pm 15$ & $3 \pm 0.3$ & $11 \pm 3$ \\
\hline $30-40$ & Intact & $180 \pm 27$ & $182 \pm 28$ & $3 \pm 0$ & $11 \pm 1$ \\
\hline $60-70$ & Intact & $179 \pm 25$ & $180 \pm 25$ & $3 \pm 0$ & $8 \pm 0$ \\
\hline $10-20$ & Dried & $212 \pm 51$ & $216 \pm 54$ & $3 \pm 1$ & $9 \pm 7$ \\
\hline
\end{tabular}

Indicator species analysis revealed that a total of 72, 10 and 102 prokaryote species associated significantly with the acrotelm, mesotelm and catotelm in the intact bog, respectively. For fungi in the intact bog, indicator species analysis revealed that Taphrina carpini (Taphrinaceae) and Symmetrospora gracilis (Symmetrosporaceae) associated significantly with the catotelm. Trichoderma sp. (Hypocreaceae) associated significantly with both acro- and mesotelm, whereas Hypochnicium huinayensis (Podoscyphaceae) associated significantly with meso- and catotelm.

\section{Soil fungal and prokaryote functional diversity}

Fungal functional guilds showed shifts among soil depths in the intact bog (Fig. 4a). The relative abundance of plant pathogens and saprotrophs was notably highest in the catotelm $(60 \mathrm{~cm})$ and lowest in the mesotelm $(30 \mathrm{~cm})$. Conversely, the relative abundance of mycorrhizas was lowest in the catotelm and highest in the mesotelm (Fig. 4a).

The differences in the relative abundance of soil fungal functional guilds were apparent between the intact bog and dried peat (Fig. 4b). Specifically, the relative abundance of plant pathogens/saprotrophs was two-fold higher in the dried peat acrotelm compared with the intact bog acrotelm (Fig. 4b). 
PiCRUSt generation of Kyoto Encyclopedia of Genes and Genomes (KEGG) assigned predicted functional content (i.e., predicted metagenome content) to 420 KEGG pathways based on the Illumina sequencing reads. Metabolic pathways were significantly different among the acro-, meso- and catotelm in the intact $\operatorname{bog}\left(F_{2,8}=6.5, P=0.03\right.$, Fig. $\left.5 a\right)$, but not between the acrotelms of the intact bog and the dried peat $\left(F_{2,4}\right.$ $=7.36, P=0.1)$. The heatmap dendrogram revealed that the catotelm metabolic profile differed from the acro- and mesotelm metabolic profiles (Fig. 5b), which were more similar and grouped together.

Indicator species analysis revealed that ten prokaryote predicted metabolic pathways contributed significantly to metabolic divergence in samples from the mesotelm and catotelm from intact bog sites (Table 4). Notably, these ten pathways were, on average, 5-fold more abundant in the catotelm than in the mesotelm (Table 4). PWY-5532 and PWY-7286 pathways were absent from all acrotelm soils, whilst PWY-7446, PWY-6713, PWY-6165, PWY-6148, PWY-6629, LPSSYN-PWY and METHANOGENESIS-PWY were absent in two out of three acrotelm soil samples from intact bog sites. Note that at least four of these pathways upregulated in the catotelm are associated with archaeal metabolism, at least two of which (PWY-6148, METHANOGENESIS-PWY) are associated with methanogenesis. 
Table 4

Ten bacterial predicted metabolic pathways that contributed significantly to soils from the mesotelm and catotelm from intact bog sites, Wellington Plains peatland, Australia. Predicted metabolic pathway description is based on the MetaCyc searches (metacyc.org).

\begin{tabular}{|c|c|c|c|c|c|}
\hline $\begin{array}{l}\text { Predicted metabolic } \\
\text { pathway name }\end{array}$ & $\begin{array}{l}\text { Predicted metabolic } \\
\text { pathway description }\end{array}$ & $\begin{array}{l}\text { Indicator } \\
\text { value }\end{array}$ & $\begin{array}{l}P- \\
\text { value }\end{array}$ & $\begin{array}{l}\text { Relative } \\
\text { average } \\
\text { abundance } \\
\text { in } \\
\text { mesotelm }\end{array}$ & $\begin{array}{l}\text { Relative } \\
\text { average } \\
\text { abundance } \\
\text { in catotelm }\end{array}$ \\
\hline PWY-5532 & $\begin{array}{l}\text { nucleoside and nucleotide } \\
\text { degradation (archaeal) }\end{array}$ & 1.00 & 0.03 & $3.1 \%$ & $28.3 \%$ \\
\hline PWY-7286 & $\begin{array}{l}\text { 7-(3-amino-3- } \\
\text { carboxypropyl)-wyosine } \\
\text { biosynthesis }\end{array}$ & 1.00 & 0.03 & $2.2 \%$ & $29.4 \%$ \\
\hline PWY-7446 & $\begin{array}{l}\text { sulfoquinovose } \\
\text { degradation I }\end{array}$ & 0.98 & 0.03 & $6.8 \%$ & $26.2 \%$ \\
\hline PWY-6713 & L-rhamnose degradation II & 0.98 & 0.03 & $7.9 \%$ & $24.9 \%$ \\
\hline PWY-6165 & $\begin{array}{l}\text { chorismate biosynthesis II } \\
\text { (archaeal) }\end{array}$ & 0.97 & 0.03 & $3.9 \%$ & $29.3 \%$ \\
\hline PWY-6148 & $\begin{array}{l}\text { tetrahydromethanopterin } \\
\text { biosynthesis, co-enzyme in } \\
\text { methanogenesis by } \\
\text { archaea }\end{array}$ & 0.97 & 0.03 & $2.3 \%$ & $30.9 \%$ \\
\hline PWY-6629 & L-tryptophan biosynthesis & 0.96 & 0.03 & $6.3 \%$ & $26.8 \%$ \\
\hline LPSSYN-PWY & $\begin{array}{l}\text { lipopolysaccharide } \\
\text { biosynthesis }\end{array}$ & 0.96 & 0.03 & $7.5 \%$ & $25.5 \%$ \\
\hline $\begin{array}{l}\text { METHANOGENESIS- } \\
\text { PWY }\end{array}$ & $\begin{array}{l}\text { methanogenesis from } \mathrm{H}_{2} \\
\text { and } \mathrm{CO}_{2} \text { (archaeal) }\end{array}$ & 0.96 & 0.03 & $4.9 \%$ & $26.9 \%$ \\
\hline METHGLYUT-PWY & methylglyoxal degradation & 0.95 & 0.02 & $6.6 \%$ & $25.9 \%$ \\
\hline
\end{tabular}

\section{Abiotic and biotic controls on soil fungal and prokaryote composition}

Both fungal and prokaryotic composition was significantly driven by soil chemistry and hydrology factors in the intact bog as revealed by dbRDA analysis (Table 2). Specifically, the fungal dbRDA model explained $22.5 \%\left(R^{2}\right.$ adj $)$ of the overall variation in the fungal composition, with dbRDA axes 1 and 2 accounting for $7.68 \%$ and $6.06 \%$ of this effect, respectively (Table 2, Fig. 6a). RDA axis 1 was statistically significant, whereas RDA axis 2 was near significant (Supplementary Table 5). Manganese (Mn), nitrogen $(\mathrm{N})$, electrical conductivity (EC) and water table level $(\mathrm{cm})$ explained best the fungal variation along the RDA axis 1 (Fig. 6a). The permutation test for the soil chemistry and hydrology factors tested in the dbRDA 
analysis revealed that $\mathrm{Mn}, \mathrm{EC}$ and water table level $(\mathrm{cm})$ were statistically significant (Supplementary Table 6). For example, we found that mean $\mathrm{Mn}(\mathrm{mg} / \mathrm{kg})$ concentration was at least 10 -fold higher in the acrotelm $331.9( \pm 162.2)(\mathrm{mg} / \mathrm{kg})$, compared with the mesotelm $39.9( \pm 15.1) \mathrm{mg} / \mathrm{kg}$ and catotelm 15.5 $( \pm 6.8) \mathrm{mg} / \mathrm{kg}$ (Supplementary Fig. 2).

The prokaryote dbRDA was statistically significant for prokaryote composition in the intact bog sites (Table 2, Fig. 6b). This model explained $23.57 \%\left(R^{2}{ }_{\text {adj }}\right)$ of the overall variation in the prokaryote composition, with dbRDA axes 1 and 2 accounting for $8.85 \%$ and $5.35 \%$ of this effect, respectively. RDA axis 1 was statistically significant $\left(F_{1,8}=2.80, P=0.009\right)$, whereas RDA axis 2 was not significant $\left(F_{1,8}=\right.$ $1.69, P=0.22$, Supplementary Table 7). Peat carbon $(C)$, nitrogen $(N)$, lead $(P b)$, sodium $(\mathrm{Na})$ and manganese $(\mathrm{Mn})$ best explained the bacterial variation along the RDA axis 1 (Fig. 6b.). However, the permutation test for the five soil chemistry factors tested in the dbRDA analysis revealed that these factors were not significant, suggesting that a combination of these factors rather than any single tested factor best explains the overall effects on bacterial composition across the three soil depths (Supplementary Table 8).

The fungal dbRDA model for intact and dried peat samples explained $5.6 \%\left(R^{2}\right.$ adj $)$ of the variation in the fungal composition (Table 2, Supplementary Fig. 1). Iron (Fe) best explained the fungal variation along the RDA axis 1 (Supplementary Fig. 1).

Mean water table position across years 2008-2015 in both dried peat and intact bog sites remained, on average, below the surface (between zero to $-15 \mathrm{~cm}$ ) (Fig. 1d and e). However, in the dried peat, the water table was above the surface for significantly longer than in the intact bog (dried peat: $\max =5.3 \mathrm{~cm}, \pm \mathrm{S}$. $E=0.2$, intact bog: $\max =-2.7, \pm S$. $E=0.1$ ) (Fig. $1 \mathrm{~d}$ and e). Notably, in the intact bog, the water table is on average $75 \%-90 \%$ of time in the acrotelm and never above the surface, whereas in the dried peat the water table is $10-40 \%$ of the time above the surface (Fig. $1 \mathrm{~d}$ and e). Thus, the water table is more variable in the dried peat site. Variable water table can recharge alternate electron acceptors, driving more microbial degradation of peat under anoxic conditions, and altering microbial communities.

\section{Discussion}

Peatlands contain a large diversity of microbial communities that differ in their resource use and the functional roles that they play in peatland ecosystems [66]. For example, fungi are critical in decomposing complex substrates [67], whereas bacteria are better at utilizing simple compounds [68]. Whilst microbial biomass has been shown to be typically high across all peat depths, microbial composition varies with peat depth as it is shaped by many factors, including moisture and oxygen availability $[23,69]$, changes in substrate and redox potential [11, 70], and carbon and soil nutrient dynamics [66].

Our results demonstrated that prokaryote structure and function (i.e., predicted metabolic pathways) were significantly different between the acro-, meso- and catotelm, consistent with our first hypothesis that 
there is a vertical stratification of prokaryote function in the intact bog soil. Prokaryote richness was highest in the intact bog mesotelm, which is in line with the previous studies that have proposed that the mesotelm forms a biogeochemical "hot spot" for microbial diversity and activity [18, 71]. We found that Proteobacteria and Acidobacteria were the dominant bacterial taxa across the acro-, meso- and catotelm, which parallels previous studies that have suggested that Proteobacteria and Acidobacteria are primarily responsible for plant biomass degradation and nutrient cycling $[72,73]$.

Carbon $(\mathrm{C})$, nitrogen $(\mathrm{N})$, lead $(\mathrm{Pb})$, sodium $(\mathrm{Na})$ and manganese $(\mathrm{Mn})$ collectively best explained the prokaryote variation as a function of soil depth in the intact bog. While we should be cautious to infer too much from correlative results in a small dataset, it is possible that the prokaryote structural and functional changes are related to the observed physico-chemical properties of peat that have been shown to change over peat depth profiles [74]. For example, we found high levels of manganese in the acrotelm. Manganese in natural environments is found as reduced soluble or adsorbed Mn (II) and insoluble Mn (III) and Mn (IV) oxides [75]. Many microorganisms, including bacteria and fungi, can oxidize Mn (II) or reduce Mn (III) or Mn (IV) oxides [76, 77]. Some authors have suggested that Mn oxides accumulated under oxic conditions, such as in the acrotelm, may be utilized by bacteria for respiration when conditions become anoxic [75, 78]. Based on our long-term water table level data, it is evident that in the intact bog, in the acrotelm conditions remain oxic most of the time, thus plausibly allowing for long-term $\mathrm{Mn}$ accumulation, whereas in the meso- and catotelm, where conditions become increasingly anoxic, the composition of bacterial communities may shift more towards bacteria that utilize $\mathrm{Mn}$ and many other inorganic and organic electron acceptors for respiration.

Prokaryote predicted metabolic pathways, similarly to their structure, were clustered by soil depth in the intact bog. This is in line with findings from other studies that have found functional differentiation of prokaryotes with soil depth $[11,79]$. Here, some of the most abundant predicted metabolic pathways in the meso- and catotelm were related to L-rhamnose degradation II, lipopolysaccharide biosynthesis pathway, sulfoquinovose degradation $\mathrm{I}$, tetrahydromethanopterin $\left(\mathrm{H}_{4} \mathrm{MPT}\right)$ biosynthesis and chorismate biosynthesis II (archaea). $\mathrm{H}_{4}$ MPT is involved in methane production and it is produced by archaea [80, 81]. We uncovered two significant metabolic pathways that are related to methanogenesis, consistent with the fact that methanogens are common in environments where anaerobic biodegradation of organic material occurs, i.e., in deeper, more anoxic meso- and catotelms [82]. In our intact bog sites, the water table level was, on average, in the acrotelm 70-90\% of time from November to March (Fig. 1d), creating anoxic conditions in the meso- and catotelm where anaerobic biodegradation of organic material can occur.

The lower prokaryote richness observed in the dried peat acrotelm compared to the intact bog acrotelm may be attributed to the differences in overall vegetation, but specifically Sphagnum moss cover. In the intact bog, we found that the Sphagnum cover ranged between $80-100 \%$, whereas in the dried peat it was $30 \%$ or less. Our results are supported by findings from Wang et al. (2019), who also reported a correlation between vegetation (Sphagnum cover) and prokaryote community structure. Furthermore, we observed that the relative abundance of Chloroflexi was notably higher in the dried peat acrotelm. Bai et 
al. (2017) have reported that slow-growing Chloroflexi are more tolerant to depleted carbon resource availability which may be caused by changes in soil chemistry due to decomposition that burns off more labile carbohydrates [83].

In contrast to prokaryotes, soil fungal community structure was not affected by soil depth in the intact bog, consistent with Wang et al. (2019) who studied minerotrophic fens in China using a similar sampling design to ours, but in contrast with Lamit et al. $(2017,2021)$ who found dramatic shifts in fungal community structure with depth. Furthermore, it is important to note that marginal sampling effort in our study may have affected the detectability of an effect of soil depth on fungal communities, similarly to Wang et al. (2019) and in contrast to Lamit et al. $(2017,2021)$ where sampling effort was greater. This is farther reflected in the lack of overall compositional shifts in soil fungi in our study, although phyla and functional guilds changed with soil depth.

Here, we found that soil fungal structure was significantly explained by manganese (Mn), electrical conductivity (EC) and water table level (cm), which is supported by several other studies that have described the important link between nutrient resources, water table level, soil moisture and soil fungi [84-87]. Specifically, soil fungi are highly susceptible to waterlogging and some fungal species are not able to tolerate anoxic conditions, which may result in considerably lower fungal richness in permanently waterlogged peatlands [88-90]. In our study site water logging is unlikely to detrimentally affect the soil fungal communities in the bog peat acrotelm as the water table does not rise above the bog surface throughout the year, in contrast with the more variable water table in the dried peatland.

Across our study sites, the dominant soil fungal phyla were Ascomycota, followed by Basidiomycota, which is in accordance with previous studies that have reported Ascomycota and Basidiomycota to dominate the soil fungal communities in peatlands globally, with average relative abundances of $46 \%$ and $40 \%$, respectively [91]. According to our indicator species analysis, four soil fungal species associated significantly with the acro-, meso- and catotelm in the intact bog. Specifically, Trichoderma sp. (Ascomycota), common soil fungi that are present in most soils, readily colonize plant roots and are known to exhibit mycoparasitism [92, 93], associated significantly with the acro- and mesotelm. Hypochnicium huinayensis (Basidiomycota) associated significantly with the meso- and catotelm and is a genus of corticoid, wood-inhabiting fungi with global distribution [94]. Taphrina carpini (Ascomycota) and Symmetrospora gracilis (Basidiomycota) associated significantly with the catotelm. Species from fungal genus Taphrina and Symmetrospora are yeast-like taxa, with Taphrina sp. known to cause plant diseases $[95,96]$. Thus, fungal species from both Ascomycota and Basidiomycota associated significantly with all soil layers in the intact bog.

In the intact bog, plant pathogens and saprotrophs increased from 25\% in the acrotelm to 95\% in the catotelm. Saprotrophs are free-living filamentous fungi that decompose organic material and thus their dominance in the deepest and organic material rich soil layer, i.e., the catotelm, is not unexpected [97]. Saprotrophic fungi are the most abundant guild described in peatland studies [91, 97]. Earlier work on the carbon chemistry of both bog peat and the dried peat from Wellington Plains peatland by Grover and 
Baldock (2013) supports these findings. Grover and Baldock (2013) found that with increasing soil depth the proportion of o-alkyl carbon decreased, while the proportion of carbonyl carbon and aryl carbon increased. The alkyl:o-alkyl ratio, an index for the extent of decomposition [98], increased consistently with soil depth.

In the intact bog, the relative abundance of putative ectomycorrhizal, endophytic and orchid mycorrhizal fungi was highest in the mesotelm ( $60 \%)$, followed by $~ 35 \%$ in the acrotelm. All fungi that classified as orchid mycorrhizal associations belonged to the genus Serendipita (family: Serendipitaceae) (Supplementary Table 2). Serendipitaceae (order Sebacinales) have been reported to display highly diverse interactions with plants and they include endophytes and other lineages that repeatedly evolved ericoid, orchid and ectomycorrhizal abilities [99]. Several known plant species found in the intact bog form these associations (A. alpina, E.paludosa, B. gunniana, E.minus and B.australe, Supplementary Table 1). The most abundant vascular plants in the intact bog were rushes from the family Restionaceae, i.e., Baloskion australe (R.Br.) B.G.Briggs \& L.A.S.Johnson (Mountain Cord-rush) and Empodisma minus (Hook.f.) L.A.S.Johnson \& D.F.Cutler (Spreading rope-rush) (Table 1). Species from the family Restionaceae are known to be predominantly nonmycorrhizal in Australia, or forming arbuscular mycorrhizal associations occasionally (Supplementary Table 1) [100, 101].

We found that plant pathogens and saprotrophs were the most abundant guilds in the dried peat acrotelm $(\sim 70 \%)$, compared to $\sim 30 \%$ in the intact bog. Saprotrophs play a central role in carbon dynamics as they decompose lignin and cellulose [102]. Differences in saprotroph abundance were attributed to variable vegetation cover and organic material content across intact bog and dried peat sites. Specifically, as mentioned above, in the intact bog, the Sphagnum cover ranged between $80-100 \%$, whereas in the dried peat Sphagnum cover was $30 \%$ or less. Understory vascular plant species cover in the dried peat was overall similar to the intact bog plant cover, dominated by Restionaceae, with the addition of species from Poaceae family. Species from the Poaceae family are usually sparsely colonized by arbuscular mycorrhizal fungi and some species are also nonmycorrhizal (Supplementary Table 1) [103]. Furthermore, the dried site cores had a much lower abundance of the ectomycorrhizal Myrtaceae genus Baeckea, likely explaining the decline in guilds that contain ectomycorrhizal fungi in the dried site cores relative to the intact site cores.

\section{Conclusions}

Our study has demonstrated that both fungal and prokaryote communities were predominantly shaped by soil abiotic factors. Peatland degradation reduced prokaryote richness and shifted the relative abundance of fungal guilds towards more saprotrophic communities. Thus, current and future changes to vegetation and environmental conditions in these peatlands are likely to lead to altered microbial structure and associated functions, which may in turn have implications for broader ecosystem function changes in these peatlands.

\section{Declarations}




\section{Acknowledgements}

We thank Alexis Marshall for helping with field sampling. We are grateful to Nate Basiliko, Michael Carson and Graeme Spiers of Laurentian University, and Shaun Watmough laboratory at Trent University, for element analyses. This study forms a part of bigger global study "Fungal, bacterial, and archaeal communities mediating $\mathrm{C}$ cycling and trace gas flux in peatland ecosystems subject to climate change," the Global Peatland Microbiome Project. The DNA sequencing work was supported by the USDA Forest Service Northern Research Station Climate Change Program, the US National Science Foundation (DEB-1 146 149), and the U.S. Department of Energy Joint Genome Institute Community Science Program (Proposal ID 1445). The work was conducted by the U.S. Department of Energy Joint Genome Institute, a DOE Office of Science User Facility, is supported by the Office of Science of the U.S. Department of Energy under Contract No. DE-AC02-05CH11231. The field sampling was supported by a Securing Food, Water and the Environment Research Grant from La Trobe University awarded to Grover "Global Peatland Microbiome Project: Australasian Node". The data analysis and writing were supported by the Australian Centre for International Agricultural Research peatlands research program projects "SLaM/2020/118 Validating technologies for assessing and monitoring the impacts of re-wetting of Indonesian peatlands using eddy flux towers coupled with Chameleon sensors" and "FST/2016/144 Improving community fire management and peatland restoration".

\section{Funding}

This study was financially supported by the USDA Forest Service Northern Research Station Climate Change Program, the US National Science Foundation (DEB-1 146 149), and the U.S. Department of Energy Joint Genome Institute Community Science Program (Proposal ID 1445). The work was conducted by the U.S. Department of Energy Joint Genome Institute, a DOE Office of Science User Facility, is supported by the Office of Science of the U.S. Department of Energy under Contract No. DE-AC0205CH11231. The field sampling was supported by a Securing Food, Water and the Environment Research Grant from La Trobe University awarded to Grover "Global Peatland Microbiome Project: Australasian Node". The data analysis and writing were supported by the Australian Centre for International Agricultural Research peatlands research program projects "SLaM/2020/118 Validating technologies for assessing and monitoring the impacts of re-wetting of Indonesian peatlands using eddy flux towers coupled with Chameleon sensors" and "FST/2016/144 Improving community fire management and peatland restoration".

\section{Competing Interests}

Not applicable.

\section{Author Contributions}

Study conception and design Jamie Lamit, Erik Lilleskov and Samantha Grover. Material preparation and data collection Samantha Grover and Jamie Lamit. Analyses were performed by Christina Birnbaum and 
Jennifer Wood. The first draft of the manuscript was written by Christina Birnbaum and all authors commented on previous versions of the manuscript. All authors read and approved the final manuscript.

\section{Data Availability}

Data and code will be made publicly available upon acceptance.

\section{Ethics approval}

Not applicable.

\section{Consent to participate}

Not applicable.

\section{Consent to publish}

Not applicable.

\section{References}

1. Tveit A, Schwacke R, Svenning MM, Urich T (2013) Organic carbon transformations in high-Arctic peat soils: key functions and microorganisms. ISME J 7:299-311. https://doi.org/10.1038/ismej.2012.99

2. Dinel H, Mathur SP, Brown A, Lغ́vesque M (1988) A field study of the effect of depth on methane production in peatland waters: Equipment and preliminary results. J Ecol 1083-1091

3. Joosten H, Sirin A, Couwenberg J, et al (2016) The role of peatlands in climate regulation. Peatl Restor Ecosyst Serv Sci policy Pract 66:

4. Grover SPP, Baldock JA (2012) Carbon chemistry and mineralization of peat soils from the Australian Alps. Eur J Soil Sci 63:129-140

5. Turetsky M, Wieder K, Halsey L, Vitt D (2002) Current disturbance and the diminishing peatland carbon sink. Geophys Res Lett 29:21

6. Grover SPP, Baldock JA (2013) The link between peat hydrology and decomposition: Beyond von Post. J Hydrol 479:130-138. https://doi.org/https://doi.org/10.1016/j.jhydrol.2012.11.049

7. Burke W (1968) The basic prinnciples of drainage on peat. 16 JUL i982 1:83

8. Davidson EA, Janssens IA (2006) Temperature sensitivity of soil carbon decomposition and feedbacks to climate change. Nature 440:165-173

9. Mastepanov M, Sigsgaard C, Dlugokencky EJ, et al (2008) Large tundra methane burst during onset of freezing. Nature 456:628-630

10. Dorrepaal E, Toet S, van Logtestijn RSP, et al (2009) Carbon respiration from subsurface peat accelerated by climate warming in the subarctic. Nature 460:616-619 
11. Andersen R, Chapman SJ, Artz RRE (2013) Microbial communities in natural and disturbed peatlands: A review. Soil Biol Biochem 57:979-994.

https://doi.org/https://doi.org/10.1016/j.soilbio.2012.10.003

12. Artz RRE (2009) Microbial community structure and carbon substrate use in northern peatlands. Carbon Cycl North Peatlands 184:111-129

13. Morales SE, Mouser PJ, Ward N, et al (2006) Comparison of bacterial communities in New England Sphagnum bogs using terminal restriction fragment length polymorphism (T-RFLP). Microb Ecol 52:34-44

14. Dedysh SN, Pankratov TA, Belova SE, et al (2006) Phylogenetic analysis and in situ identification of bacteria community composition in an acidic Sphagnum peat bog. Appl Environ Microbiol 72:21102117

15. Thormann MN (2011) In vitro decomposition of Sphagnum-derived acrotelm and mesotelm peat by indigenous and alien basidiomycetous fungi. Mires Peat 8 :

16. Clymo RS, Bryant CL (2008) Diffusion and mass flow of dissolved carbon dioxide, methane, and dissolved organic carbon in a 7-m deep raised peat bog. Geochim Cosmochim Acta 72:2048-2066

17. Groß-Schmölders $M$, von Sengbusch $P$, Krüger JP, et al (2020) Switch of fungal to bacterial degradation in natural, drained and rewetted oligotrophic peatlands reflected in $\backslash$ chem $\{\backslash$ delta $\{15\} N\}$ and fatty acid composition. SOIL 6:299-313. https://doi.org/10.5194/soil-6-299-2020

18. Morris PJ, Waddington JM, Benscoter BW, Turetsky MR (2011) Conceptual frameworks in peatland ecohydrology: looking beyond the two-layered (acrotelm-catotelm) model. Ecohydrology 4:1-11

19. Lin X, Tfaily MM, Green SJ, et al (2014) Microbial metabolic potential for carbon degradation and nutrient (nitrogen and phosphorus) acquisition in an ombrotrophic peatland. Appl Environ Microbiol 80:3531-3540

20. Clymo RS (1984) The limits to peat bog growth. Philos Trans R Soc London B, Biol Sci 303:605-654

21. Lamit LJ, Romanowicz KJ, Potvin LR, et al (2017) Patterns and drivers of fungal community depth stratification in Sphagnum peat. FEMS Microbiol Ecol 93:. https://doi.org/10.1093/femsec/fix082

22. Asemaninejad A, Thorn RG, Branfireun BA, Lindo Z (2018) Climate change favours specific fungal communities in boreal peatlands. Soil Biol Biochem 120:28-36. https://doi.org/https://doi.org/10.1016/j.soilbio.2018.01.029

23. Lamit LJ, Romanowicz KJ, Potvin LR, et al (2021) Peatland microbial community responses to plant functional group and drought are depth-dependent. Mol Ecol n/a: https://doi.org/https://doi.org/10.1111/mec.16125

24. Martí M, Juottonen $H$, Robroek BJM, et al (2015) Nitrogen and methanogen community composition within and among three Sphagnum dominated peatlands in Scandinavia. Soil Biol Biochem 81:204211. https://doi.org/https://doi.org/10.1016/j.soilbio.2014.11.016

25. Godin A, McLaughlin JW, Webster KL, et al (2012) Methane and methanogen community dynamics across a boreal peatland nutrient gradient. Soil Biol Biochem 48:96-105. https://doi.org/https://doi.org/10.1016/j.soilbio.2012.01.018 
26. Kuehn KA, Lemke MJ, Suberkropp K, Wetzel RG (2000) Microbial biomass and production associated with decaying leaf litter of the emergent macrophyte Juncus effusus. Limnol Oceanogr 45:862-870

27. Williams RT, Crawford RL (1983) Microbial diversity of Minnesota peatlands. Microb Ecol 9:201-214

28. Golovchenko A V, Tikhonova EY, Zvyagintsev DG (2007) Abundance, biomass, structure, and activity of the microbial complexes of minerotrophic and ombrotrophic peatlands. Microbiology 76:630-637

29. Lumley TC, Gignac LD, Currah RS (2001) Microfungus communities of white spruce and trembling aspen logs at different stages of decay in disturbed and undisturbed sites in the boreal mixedwood region of Alberta. Can J Bot 79:76-92

30. Peltoniemi K, Straková P, Fritze H, et al (2012) How water-level drawdown modifies litterdecomposing fungal and actinobacterial communities in boreal peatlands. Soil Biol Biochem 51:2034

31. Francez A-J, Gogo S, Josselin N (2000) Distribution of potential CO2 and CH4 productions, denitrification and microbial biomass $\mathrm{C}$ and $\mathrm{N}$ in the profileof a restored peatland in Brittany (France). Eur J Soil Biol 36:161-168

32. Hanson RS, Hanson TE (1996) Methanotrophic bacteria. Microbiol Rev 60:439-471

33. Toberman H, Freeman C, Evans C, et al (2008) Summer drought decreases soil fungal diversity and associated phenol oxidase activity in upland Calluna heathland soil. FEMS Microbiol Ecol 66:426436

34. Trinder CJ, Johnson D, Artz RRE (2008) Interactions among fungal community structure, litter decomposition and depth of water table in a cutover peatland. FEMS Microbiol Ecol 64:433-448

35. Jaatinen K, Laiho R, Vuorenmaa A, et al (2008) Responses of aerobic microbial communities and soil respiration to water-level drawdown in a northern boreal fen. Environ Microbiol 10:339-353

36. Kim S-Y, Lee S-H, Freeman C, et al (2008) Comparative analysis of soil microbial communities and their responses to the short-term drought in bog, fen, and riparian wetlands. Soil Biol Biochem 40:2874-2880

37. Jaatinen K, Tuittila E-S, Laine J, et al (2005) Methane-oxidizing bacteria in a Finnish raised mire complex: effects of site fertility and drainage. Microb Ecol 50:429-439

38. Grover SPP, McKenzie BM, Baldock JA, Papst WA (2006) Chemical characterisation of bog peat and dried peat of the Australian Alps. Soil Res 43:963-971

39. Grover SPP, Baldock JA, Jacobsen GE (2011) Accumulation and attrition of peat soils in the Australian Alps: Isotopic dating evidence. Austral Ecol 37:510-517

40. Wahren CHA, Papst WA (1999) Post-fire regeneration in sub-alpine vegetation on Holmes and Wellington Plains. Melbourne, Aust Alps Liaison Comm

41. Whinam J, Hope G, Good R, Wright G (2010) Post-fire experimental trials of vegetation restoration techniques in the peatlands of Namadgi (ACT) and Kosciuszko National Parks (NSW), Australia. Altered Ecol fire, Clim Hum Influ Terr landscapes (Terra Aust 32) ANU ePress, Canberra 363-379 
42. Good R, Wright G, Whinam J, Hope GS (2010) Restoration of mires of the Australian Alps following the 2003 wildfires. JSTOR

43. Grover SPP, Baldock JA (2010) Carbon decomposition processes in a peat from the Australian Alps. Eur J Soil Sci 61:217-230

44. Grover SPP (2006) Carbon and water dynamics of peat soils in the Australian Alps. PhD Thesis. La Trobe University. Melbourne.

45. Elwood C (2001) Dynamics of a subalpine peat bog on the Wellington Plain, Victoria. A Long-Term Perspective for the Assessment of the Impacts of Cattle Grazing. Honours Thesis. Monash University, Melbourne

46. Seward J, Carson MA, Lamit LJ, et al (2020) Peatland Microbial Community Composition Is Driven by a Natural Climate Gradient. Microb Ecol. https://doi.org/10.1007/s00248-020-01510-z

47. Caporaso JG, Lauber CL, Walters WA, et al (2011) Global patterns of $16 \mathrm{~S}$ rRNA diversity at a depth of millions of sequences per sample. Proc Natl Acad Sci 108:4516-4522

48. Ihrmark K, Bödeker ITM, Cruz-Martinez K, et al (2012) New primers to amplify the fungal ITS2 region - evaluation by 454-sequencing of artificial and natural communities. FEMS Microbiol Ecol 82:666677. https://doi.org/10.1111/j.1574-6941.2012.01437.x

49. White T, Burns T, Lee S, Taylor J 1990. (1990) Analysis of phylogenetic relationship by amplification and direct sequencing of ribosomal RNA genes. In: Innis MA, Gelfand DH, Sninsky JJ, White TJ (eds) PCR Protocols: A Guide to Methods and Applications. Academic Press, New York, pp 315-322

50. Bolyen E, Rideout JR, Dillon MR, et al (2019) Reproducible, interactive, scalable and extensible microbiome data science using QIIME 2. Nat Biotechnol 37:852-857

51. Callahan BJ, McMurdie PJ, Rosen MJ, et al (2016) DADA2: high-resolution sample inference from Illumina amplicon data. Nat Methods 13:581-583

52. Price MN, Dehal PS, Arkin AP (2010) FastTree 2-approximately maximum-likelihood trees for large alignments. PLoS One 5:e9490

53. Bokulich NA, Kaehler BD, Rideout JR, et al (2018) Optimizing taxonomic classification of marker-gene amplicon sequences with QIIME 2's q2-feature-classifier plugin. Microbiome 6:90

54. McDonald D, Price MN, Goodrich J, et al (2012) An improved Greengenes taxonomy with explicit ranks for ecological and evolutionary analyses of bacteria and archaea. ISME J 6:610-618

55. Kõljalg U, Larsson K-H, Abarenkov K, et al (2005) UNITE: a database providing web-based methods for the molecular identification of ectomycorrhizal fungi. New Phytol 166:1063-1068. https://doi.org/10.1111/j.1469-8137.2005.01376.x

56. Douglas GM, Maffei VJ, Zaneveld J, et al (2019) PICRUSt2: An improved and extensible approach for metagenome inference. bioRxiv 672295. https://doi.org/10.1101/672295

57. Nguyen NH, Song Z, Bates ST, et al (2016) FUNGuild: An open annotation tool for parsing fungal community datasets by ecological guild. Fungal Ecol 20:241-248. https://doi.org/http://dx.doi.org/10.1016/j.funeco.2015.06.006 
58. Egidi E, Wood JL, Celestina C, et al (2019) Delving into the dark ecology: A continent-wide assessment of patterns of composition in soil fungal communities from Australian tussock grasslands. Fungal Ecol 39:356-370. https://doi.org/https://doi.org/10.1016/j.funeco.2019.03.001

59. McMurdie PJ, Holmes S (2013) phyloseq: an R package for reproducible interactive analysis and graphics of microbiome census data. PLoS One 8:e61217

60. Oksanen J, Blanchet FG, Friendly M, et al (2017) vegan: Community Ecology Package. R package version 2.4-3. http://CRAN.R-project.org/package=vegan

61. De Cáceres M (2013) How to use the indicspecies package (ver. 1.6.7). Indicspecies online tutorial

62. Kuznetsova A, Brockhoff PB, Christensen RHB (2017) ImerTest Package: Tests in Linear Mixed Effects Models. J Stat Softw B2:1-26. https://doi.org/https://doi.org/10.18637/jss.v082.i13

63. Wickham H (2009) ggplot2: Elegant Graphics for Data Analysis

64. Neuwirth E (2014) RColorBrewer: ColorBrewer Palettes. R package version 1.1-2. https://cran.rproject.org/web/packages/RColorBrewer/

65. R Core Team (2018) R: A Language and Environment for Statistical Computing. R Foundation for Statistical Computing, Vienna, Austria. URL https://www.R-project.org/

66. Asemaninejad A, Thorn RG, Lindo Z (2017) Vertical distribution of fungi in hollows and hummocks of boreal peatlands. Fungal Ecol 27:59-68

67. Sassi M Ben, Dollinger J, Renault P, et al (2012) The FungiResp method: an application of the MicroResp ${ }^{\mathrm{TM}}$ method to assess fungi in microbial communities as soil biological indicators. Ecol Indic 23:482-490

68. Rinnan R, Bååth E (2009) Differential utilization of carbon substrates by bacteria and fungi in tundra soil. Appl Environ Microbiol 75:3611-3620

69. Song L, Gilbert D, Wu D (2016) Vertical micro-distribution of microbial communities living in Sphagnum fallax. Aquat Microb Ecol 77:1-10

70. Basiliko N, Blodau C, Roehm C, et al (2007) Regulation of decomposition and methane dynamics across natural, commercially mined, and restored northern peatlands. Ecosystems 10:1148-1165

71. Xueju L, M. TM, Megan SJ, et al (2014) Microbial Community Stratification Linked to Utilization of Carbohydrates and Phosphorus Limitation in a Boreal Peatland at Marcell Experimental Forest, Minnesota, USA. Appl Environ Microbiol 80:3518-3530. https://doi.org/10.1128/AEM.00205-14

72. Juottonen $\mathrm{H}$, Eiler A, Biasi C, et al (2017) Distinct anaerobic bacterial consumers of cellobiose-derived carbon in boreal fens with different $\mathrm{CO} 2 / \mathrm{CH} 4$ production ratios. Appl Environ Microbiol 83:e02533-16

73. Kanokratana P, Uengwetwanit T, Rattanachomsri U, et al (2011) Insights into the Phylogeny and Metabolic Potential of a Primary Tropical Peat Swamp Forest Microbial Community by Metagenomic Analysis. Microb Ecol 61:518-528. https://doi.org/10.1007/s00248-010-9766-7

74. Too CC, Keller A, Sickel W, et al (2018) Microbial community structure in a Malaysian tropical peat swamp forest: the influence of tree species and depth. Front Microbiol 9:2859 
75. Gounot A-M (1994) Microbial oxidation and reduction of manganese: consequences in groundwater and applications. FEMS Microbiol Rev 14:339-349

76. Ghiorse WC (1984) Biology of iron-and manganese-depositing bacteria. Annu Rev Microbiol 38:515550

77. Lovley DR, Holmes DE, Nevin KP (2004) Dissimilatory fe (iii) and mn (iv) reduction. Adv Microb Physiol 49:219-286

78. Nealson KH, Tebo BM, Rosson RA (1988) Occurrence and mechanisms of microbial oxidation of manganese. Adv Appl Microbiol 33:279-318

79. Wang M, Tian J, Bu Z, et al (2019) Structural and functional differentiation of the microbial community in the surface and subsurface peat of two minerotrophic fens in China. Plant Soil 437:21-40. https://doi.org/10.1007/s11104-019-03962-w

80. Mander L, Liu H-W (2010) Comprehensive natural products II: chemistry and biology. Elsevier

81. Kalyuzhnaya MG, Beck DAC, Chistoserdova L (2011) Chapter six - Functional Metagenomics of Methylotrophs. In: Rosenzweig AC, Ragsdale SWBT-M in E (eds) Methods in Methane Metabolism, Part B: Methanotrophy. Academic Press, pp 81-98

82. Jones WJ, Nagle Jr DP, Whitman WB (1987) Methanogens and the diversity of archaebacteria. Microbiol Rev 51:135-177

83. Normand AE, Turner BL, Lamit LJ, et al (2021) Organic matter chemistry drives carbon dioxide production of peatlands. Geophys Res Lett 48:e2021GL093392

84. Peay KG, Kennedy PG, Talbot JM (2016) Dimensions of biodiversity in the Earth mycobiome. Nat Rev Microbiol 14:434-447

85. Juan-Ovejero R, Briones MJI, Öpik M (2020) Fungal diversity in peatlands and its contribution to carbon cycling. Appl Soil Ecol 146:103393.

https://doi.org/https://doi.org/10.1016/j.apsoil.2019.103393

86. Hájek $M$, Horsák $M$, Hájková $P$, Dítě $D$ (2006) Habitat diversity of central European fens in relation to environmental gradients and an effort to standardise fen terminology in ecological studies. Perspect Plant Ecol Evol Syst 8:97-114

87. Waldrop MP, Zak DR, Blackwood CB, et al (2006) Resource availability controls fungal diversity across a plant diversity gradient. Ecol Lett 9:1127-1135

88. Mäkiranta P, Laiho R, Fritze H, et al (2009) Indirect regulation of heterotrophic peat soil respiration by water level via microbial community structure and temperature sensitivity. Soil Biol Biochem 41:695703

89. Mpamah PA, Taipale S, Rissanen AJ, et al (2017) The impact of long-term water level draw-down on microbial biomass: a comparative study from two peatland sites with different nutrient status. Eur $\mathrm{J}$ Soil Biol 80:59-68

90. Hiiesalu I, Bahram M, Tedersoo L (2017) Plant species richness and productivity determine the diversity of soil fungal guilds in temperate coniferous forest and bog habitats. Mol Ecol 26:4846- 
4858

91. Thormann MN, Rice A V (2007) Fungi from peatlands. Fungal Divers 24:299

92. Lorito M, Woo SL, Fernandez IG, et al (1998) Genes from mycoparasitic fungi as a source for improving plant resistance to fungal pathogens. Proc Natl Acad Sci 95:7860-7865

93. Kubicek CP, Harman GE (1998) Trichoderma and Gliocladium. Volume 1: Basic biology, taxonomy and genetics. Taylor and Francis Ltd

94. Telleria MT, Duenas M, Melo I, et al (2010) A re-evaluation of Hypochnicium (Polyporales) based on morphological and molecular characters. Mycologia 102:1426-1436

95. Kurtzman C, Fell JW, Boekhout T (2011) The yeasts: a taxonomic study. Elsevier

96. Haelewaters D, Toome-Heller M, Albu S, Aime MC (2020) Red yeasts from leaf surfaces and other habitats: Three new species and a new combination of Symmetrospora (Pucciniomycotina, Cystobasidiomycetes). Fungal Syst Evol 5:187

97. Thormann MN (2006) Diversity and function of fungi in peatlands: a carbon cycling perspective. Can J soil Sci 86:281-293

98. Baldock JA, Oades JM, Nelson PN, et al (1997) Assessing the extent of decomposition of natural organic materials using solid-state 13C NMR spectroscopy. Soil Res 35:1061-1084

99. Weiß M, Waller F, Zuccaro A, Selosse M-A (2016) Sebacinales - one thousand and one interactions with land plants. New Phytol 211:20-40. https://doi.org/https://doi.org/10.1111/nph.13977

100. Brundrett MC, Tedersoo L (2018) Evolutionary history of mycorrhizal symbioses and global host plant diversity. New Phytol 220:1108-1115. https://doi.org/https://doi.org/10.1111/nph.14976

101. Meney KA, Dixon KW, Scheltema M, Pate JS (1993) Occurrence of vesicular mycorrhizal fungi in dryland species of Restionaceae and Cyperaceae from south-west Western Australia. Aust J Bot 41:733-737

102. Tedersoo L, Bahram M, Põlme S, et al (2014) Global diversity and geography of soil fungi. Science (80-) 346:

103. Brundrett MC (2008) Mycorrhizal Associations: The Web Resource. Date accessed 16/08/2021. «mycorrhizas.info〉.

\section{Figures}



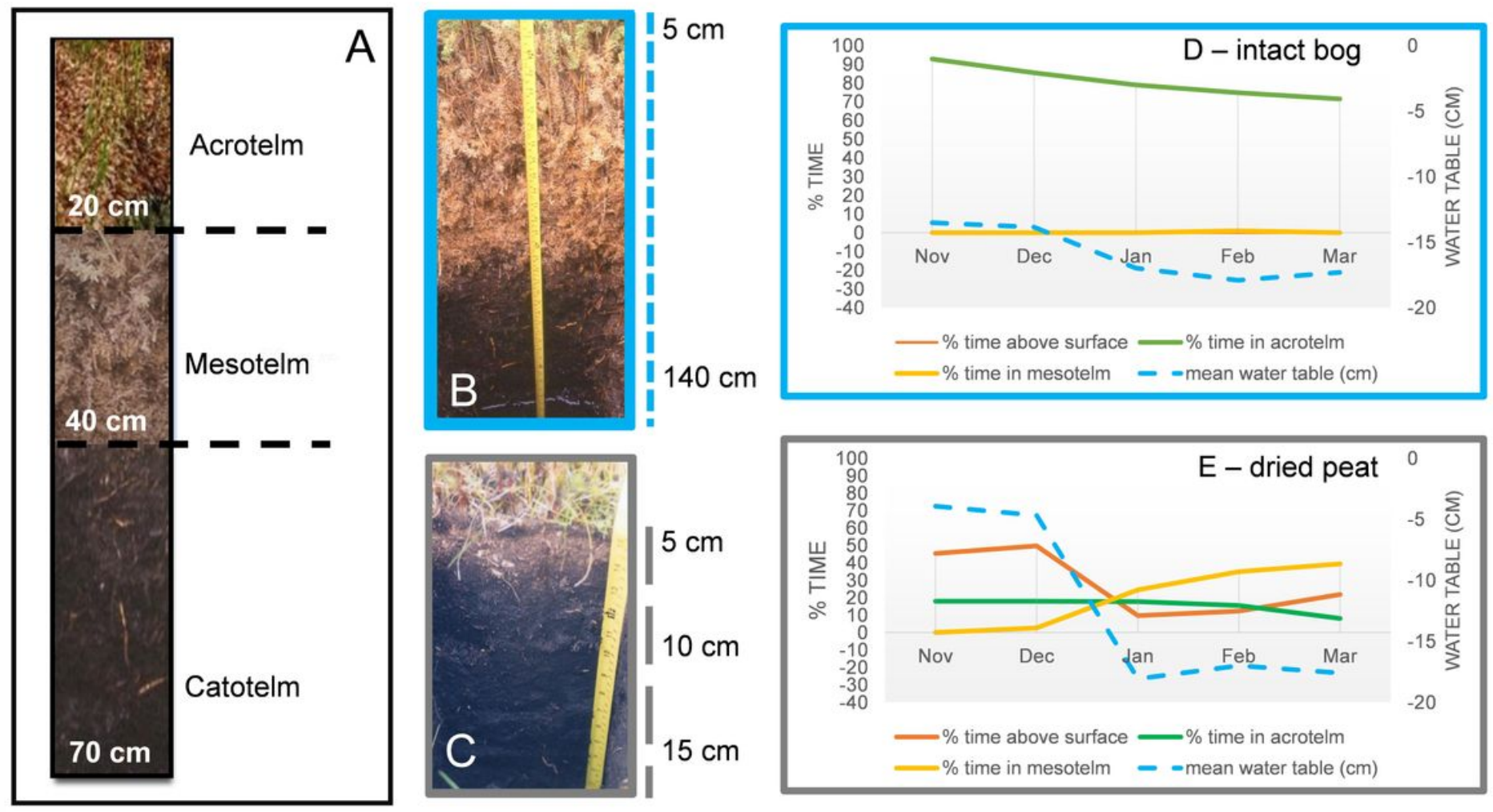

\section{Figure 1}

Schematic representation of acrotelm, mesotelm and catotelm peat profile and soil depths (A). Profile photo of intact bog (B) and dried peat (C) from Grover et al. (2011) showing peat profiles from the Wellington Plains peatland adjacent to our sampling sites. Reproduced with permission. Mean water table position $(\mathrm{cm})$ and mean \% time the water table is at different depths from November to March (plant growing season) in the intact bog (D) and dried peat (E) sites in Wellington Plains peatland, Australia is shown for the period 2008-2015. In intact bog (D), the water table is $70-90 \%$ of time in the acrotelm and never above the surface, whereas in the dried peat the water table residency $\%$ time fluctuates throughout the year and the water table level is 10-50\% of time above surface, especially in November and December (E). Peat sampling in dried peat and intact bog was conducted in March 2015. 


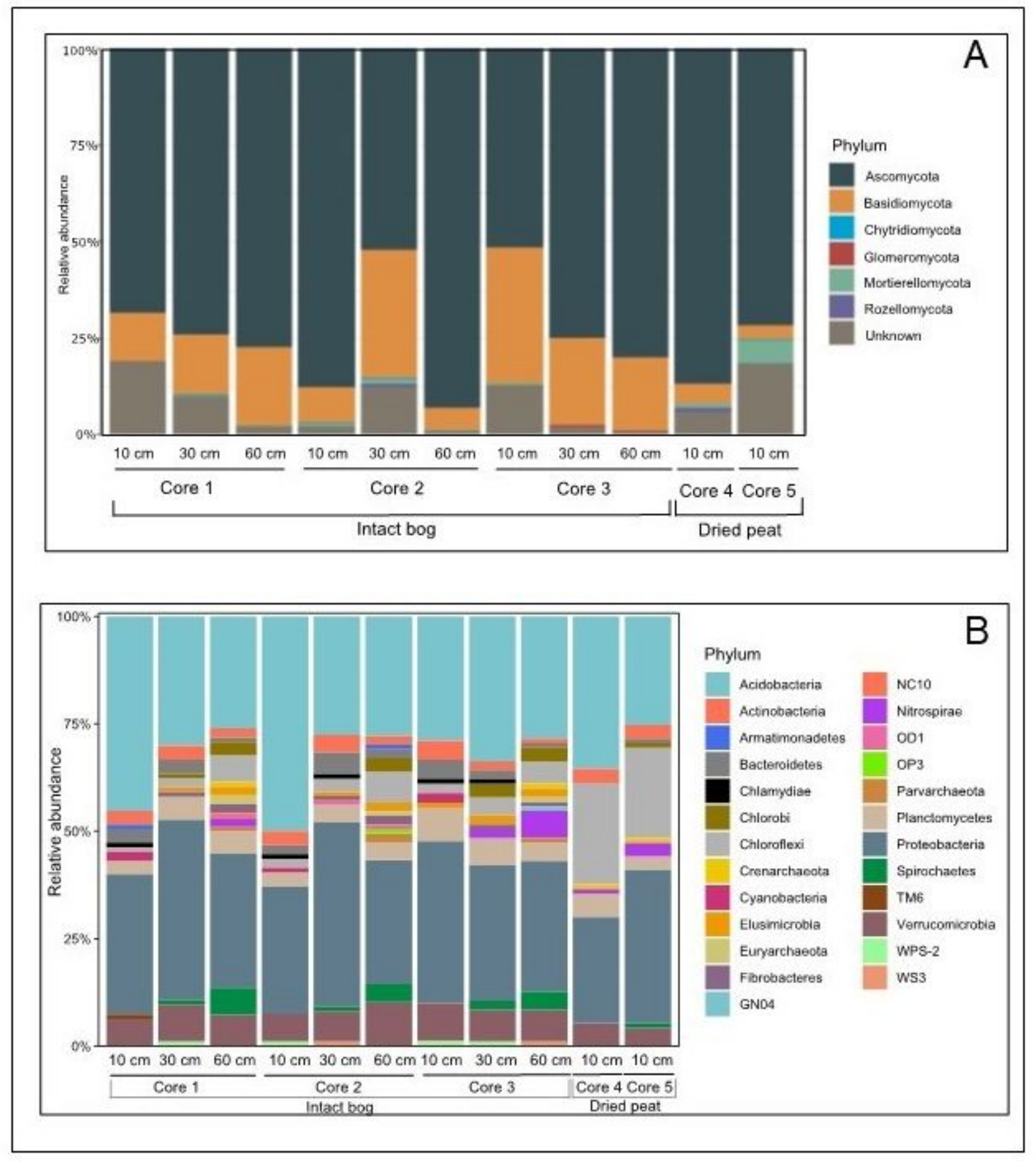

Figure 2

Relative abundance of fungi (A) and prokaryotes (B) (Phylum level) in acrotelm (10 cm), mesotelm (30 $\mathrm{cm})$ and catotelm $(60 \mathrm{~cm})$ from intact bog and dried peat cores from Wellington Plains peatland, Australia. Full list of fungal taxonomic assignments is available in Supplementary Table 2. Relative abundances of dominant prokaryote phyla are available in Supplementary Table 3. 


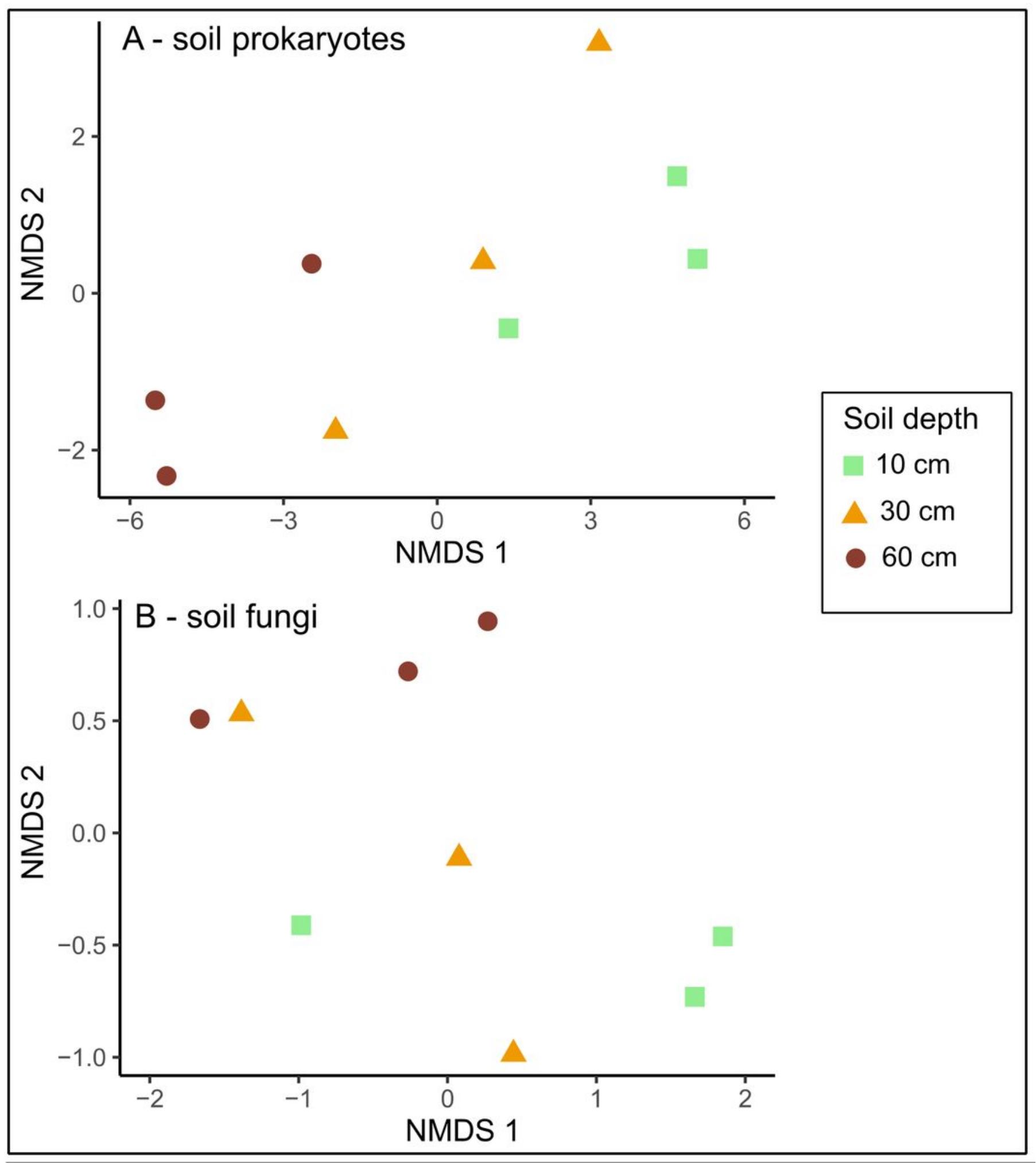

Figure 3

Non-metric multidimensional scaling ordination for (a) prokaryote and (b) fungal communities based on extracted DNA from intact bog soils collected from the acrotelm $(10 \mathrm{~cm})$, mesotelm $(30 \mathrm{~cm})$ and the catotelm $(60 \mathrm{~cm})$ from Wellington Plains peatland, Australia. 

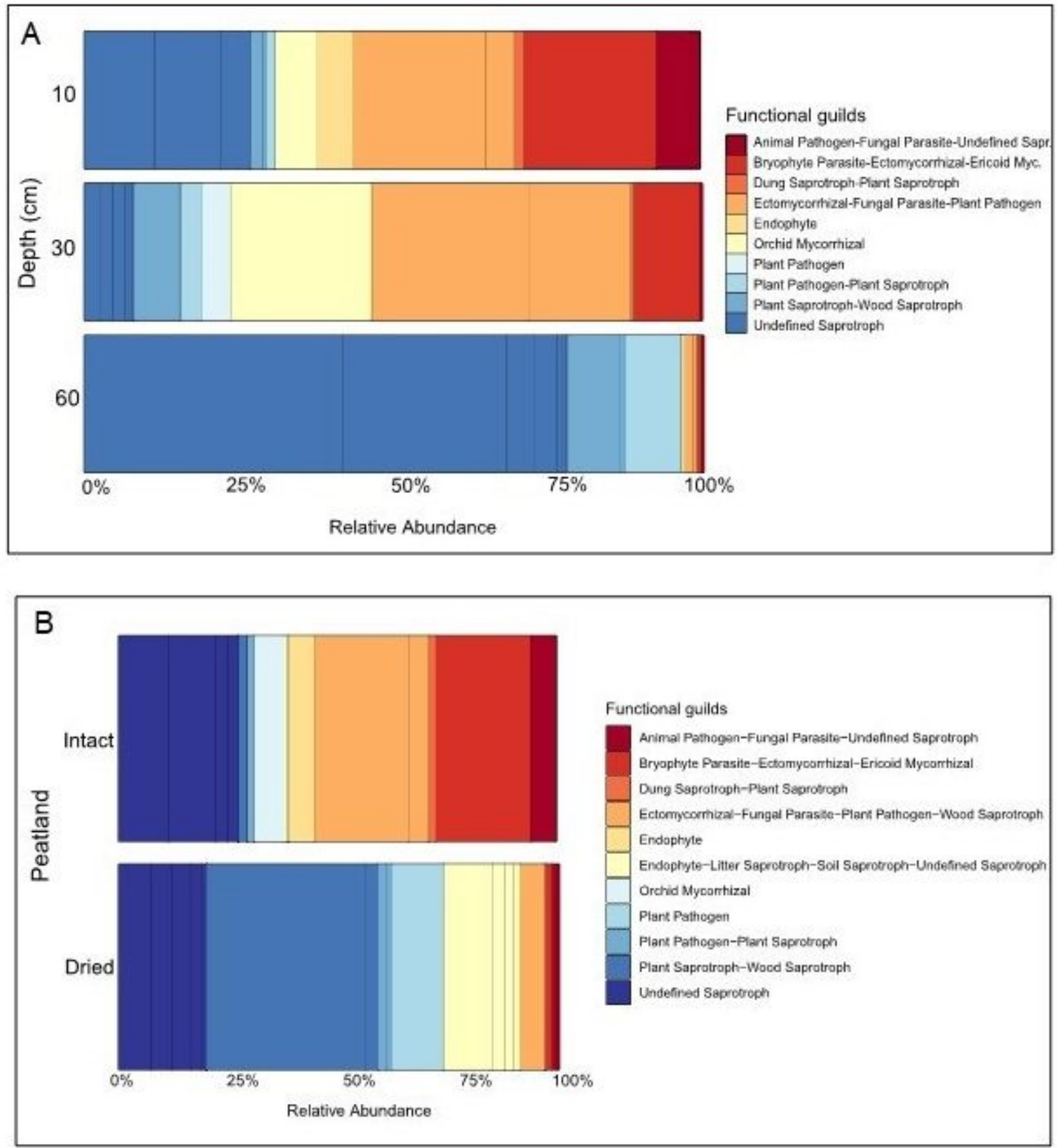

\section{Figure 4}

Guild level relative abundance of the soil fungal community in the acrotelm, mesotelm and catotelm in the intact bog $(A)$ and in the acrotelm of the intact bog and dried peat (B) from Wellington Plains peatland, Australia. 
Non-metric multidimensional scaling ordination (A) and heatmap (B) for predicted bacterial 420 KEGG pathways based on extracted DNA from intact bog soils from the acrotelm, mesotelm and catotelm from Wellington Plains peatland, Australia. The heatmap with dendrograms is scaled by "row" which corresponds to predicted metabolic pathway. The column corresponds to soil depth. Each observation is a row and each square is a value. For clarity, only predicted metabolic pathways are shown on the left that returned a descriptive metabolic profile name. For full list of predicted metabolic pathways, please see the Supplementary Table 4.
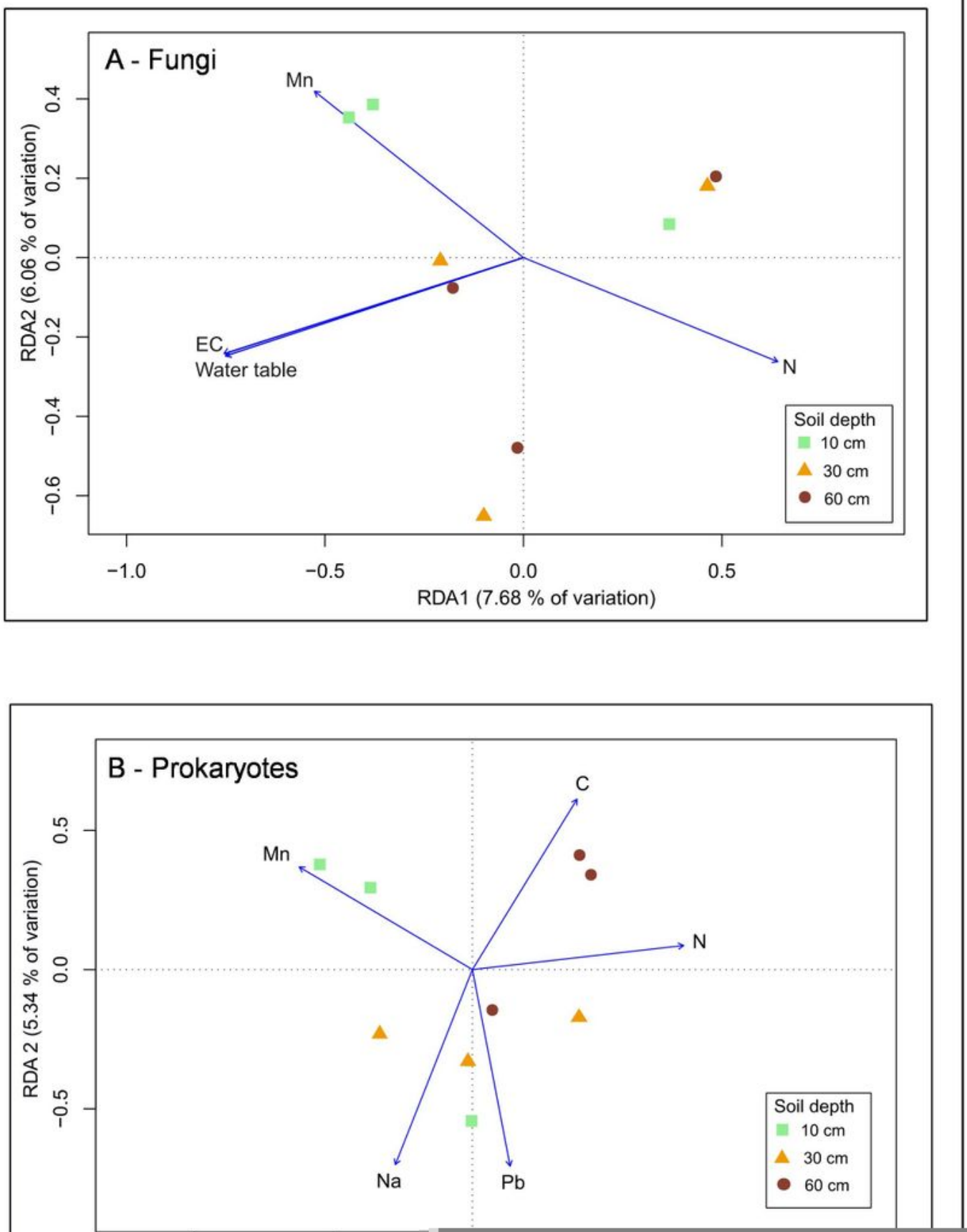
Figure 6

dbRDA biplot for fungal (A) and prokaryote (B) communities in intact bog soil from acrotelm, mesotelm and catotelm based on extracted DNA from soil from Wellington Plains peatland, Australia.

\section{Supplementary Files}

This is a list of supplementary files associated with this preprint. Click to download.

- SuppTable1prokaryotemetabolicpathways.xlsx

- SuppTable2fungaltaxafinal.xlsx

- SuppTable3prokaryotephyla.xlsx

- SuppmaterialVICplainssoilmicrobesv3.docx 